\title{
ヒト尿性カリクレインの研究
}

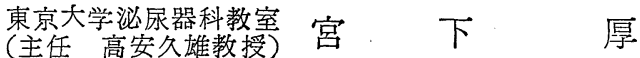

\section{URINARY KALLIKREIN DETERMINATION AND ITS PHYSIOLOGICAL ROLE IN HUMAN KIDNEY}

\author{
Atsushi Miyashita \\ Department of Urology, Faculty of Medicine, the University of Tokyo
}

(Director: Prof. H. Takayasu)

On the purpose to investigate the physiological role of kallikrein in the human kidney, its activity in human urine (Human urinary kalikrein; H.U.K.) was determined by TAME (p-toluene sulfonyl-1Arginine methyl ester) assay described by Moriya.

The values obtained with this method well correlated to those obtained as kinin releasing activity where released kinins were assayed by observing the contraction of isolated guinea pig ileum.

To obtain normal range, 6 healthy males and females were examined. The results were as follows: male, average 63 E.U. per day (ranged 0-126); female, average 39 E.U. per day (ranged 0-68).

H.U.K. activity in patients with primary aldosteronism showed significant high values. In patients with Cushing's syndrome, renal lesions and others were within normal range. H.U.K. in primary aldosteronism decreased after extirpation of the adrenal adenoma.

H.U.K. activities in 7 cases of renal homotransplantation were determined serially. Soon after the transplantation, most cases of them showed extremely low levels but in some cases showed relatively high levels.

In the cases which showed relatively high levels, the activity also decreased gradually and became almost zero before their endstadium. In 3 cases out of 6 who finally succumbed, as Werle reported, H.U.K. decreased before blood urea nitrogen level increased.

The role of kallikrein in primary aldosteronism was discussed from the standpoint of sodium and water balance and it is suggested that kallikrein in human kidney may be one of the factors controlling homeostasis of human body.

The decrease of H.U.K. in the patients of renal transplantation is thought to be ascribable to tubular dysfunction or destruction caused by the rejection reaction.

The reason why H.U.K. diminishes before blood urea nitrogen levels rise may be that tubular cells are more easily damaged than glomerular cells under ischemic conditions.

\footnotetext{
緒言

カリクレインーキニン系は, 血液凝固系, プラスミン 系と同じょうに生体の内部環境の維持に関与する酵素系 として注目され，いくつかの疾患の病態生理に本酵素系 の代謝が関係していることが明らかになつて来た。

尿中のカリクレインは, 最近, 腎に括いて生成, 排泄 されていることがわかつて来たが生体の中で特に腎にお ける生理作用についてはよく解明されていない。

腎は, 生体の水, 電解質代謝の中心であり, 副腎もま
}

た皮質ホルモンにより腎または，血管系に対して大きな 影響力をるつている. 著者は, ヒトの尿性カリクレイン （以下 H.U.K. と略称）の 1 日排泄量を主として, 腎 呿よび副腎疾患症例について測定し, 併せて, 尿細管機 能との関係についても検討し，腎に拉けるカリクレイン 一キニン系の意義について考察を試みた。

\section{対 象}

東大病院泌尿器科拉よび三楽病院の入院患者の 24 時間 尿の H.U.K. 排泄量を測定した。患者の年令は, 疾患 
により異なるが，2才から78才，男78例，女34例，合計 112例である. 疾患別では，腎疾患として腎結核 9 例, 腎腫瘍 7 例, 水腎症11例, 尿路結石（腎拈よび尿管結石 で水腎のないもの） 15例，前立腺疾患として，腫瘍10 例，肥大症16例，副腎疾患として，原発性アルドステロ ン症10例, クッシング症候群 5 例, 副腎手術の対照とし て腎, 副婜と関係の少いと考兄られる一般外科患者（胃 潰瘍 5 例, 胆石症 5 例), 同種腎移植の術後 7 例, 正常值 を調べるために，健康男女それぞれ6例である．なお， 腎移植例は，移植後数カ月間隔で測定したが，早期拒絶 反応期の尿は，血尿，混浊等のため測定に適さないもの もあつたので, このような尿は, 測定対象から除外し た。

\section{方 法}

H.U.K. の測定は，守屋の発表した比色法 ${ }^{1)}$ （図 1） を用いた。

すなわち，H.U.K. を含む試料と TAMe（アルギニ ンェステルの一種）の一定量を一定時間（1 時間）イン キニベイトしたのち，アルカリ性ヒドロキシルアミンと 作用させると分解されずに残つた基質（TAMe）により ヒドロキサミック酸が生成され，一定時間後トリクロー

\section{図 1 測定方法の概略}

\section{Colorimetric Method}

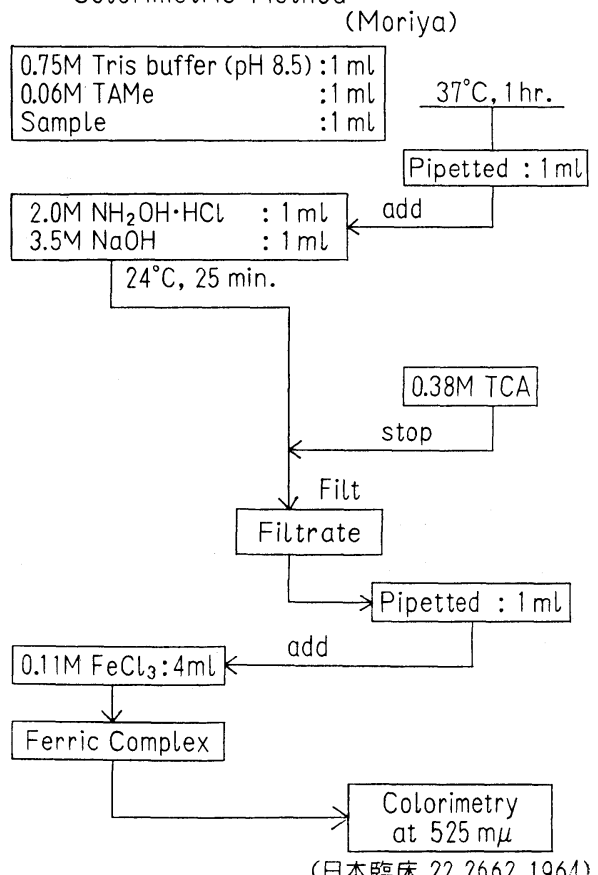

ル酢酸で反応を停止，一定量 の塩化第二鉄 とコンプレ ックスを作らせ，生じた赤色を光電比色計により測定し た，もし検体である酵素のかわりにコントロールとして 水を使えば，TAMe は分解されず，こ机による発色は 100\%となる. 標準 H.U.K. は，理科大学守屋教授よ り提供を受けた粗製 H.U. K.を用い，また，この assay に用いた試薬は次の通りである.

0.75M-Tris-buffer Solution (pH 8.5)

(特級)

2.0 M-NH${ }_{2} \mathrm{OH} . \mathrm{HCl}$ Solution

3.5 M-NaOH Solution

$0.38 \mathrm{M}$-Trichloro-acetic acid Solution

$0.11 \mathrm{M}-\mathrm{FeCl}_{3}$ Solution

TAMe (p-toluene sulfonyl-1-Arginine methyl ester)

(Sigma 化学)

合成ブラジキニン (Sandoz 薬品)

光電比色計は, 日立製作所製のベックマン型 (E-P-U 2A）を使用した。

尿の採取，濃縮方法は，次の通りである，蓄尿びんに 少量のトルェンをいれ，冷暗所にて蓄尿し，24時間尿の 一部 $300 \mathrm{ml}$ をセロファンチューブにいれ，尿量の約 $1 / 10$ 重量のポリエチレングリコールを用い，冷蔵庫内で24〜 48時間内に約50〜60倍の濃縮を行なつた. PSP テスト は，臨床検査の一環として早朝空腹時に行なつた。

\section{測 定 法}

1）Webster によれば，H.U.K.のエステラーゼ活性 は，血管拡張作用に基づく検定結果とよく一致すること が報告されている1)。したがつて，本法に打ける1 E.U. (Esterase Unit) は，1 F.U. (Frey Unit) 飞相当すると いえるが，効力既知の標準 H.U.K. を用い，用量と吸 光度の関係を調べた（図 2 ). $2 \sim 6$ E.U./ml の間では， O.D. (吸光度) と E.U. は直線関係を有しているので, 標本の測定は，すべてこの範团で計測できるように必要 に応じて稀釈系列を作成した。

2）キニン遊離能との比較検討

任意にとり出した濃縮尿の 21 検体について, TAMe 活 性とキニン遊離能による H.U.K. 活性を比較検討した. キニン遊離能は，ウシのプソイドグロブリンを基質と し，遊離キニンをモルモット回腸収縮作用を利用して測 定した。Standard としては，合成ブラジキニンを用い たそその結果，両測定値の間に相間関係(相関係数 0.78 ) が認められた（図3）.

3）回収率

標準 H.U.K. 25E.U. (25mg)，5 E.U.（5 mg）を， 
図 2 Standard H.U.K. ( 1 E.U./mg) を用いて TA Me Assay による吸光度より $1 \mathrm{ml}$ 当りの $\mathrm{E}$. U. との関係を求めた。 (E.U./ml, H.U.K.)

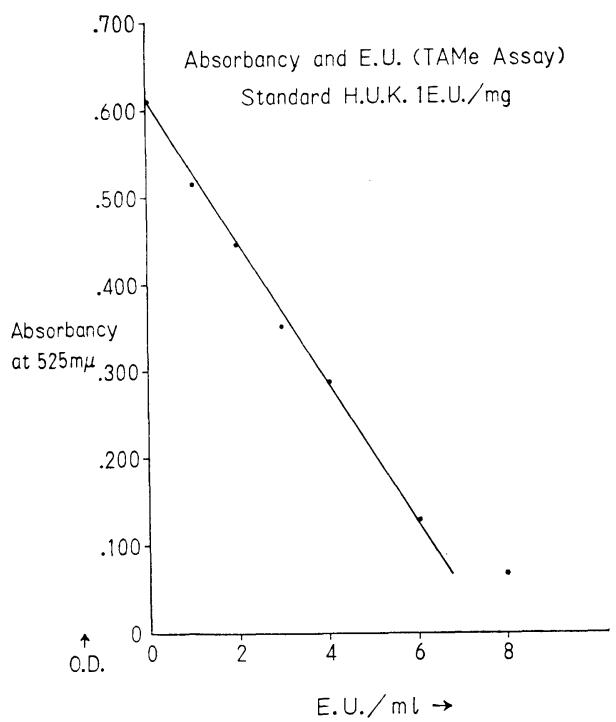

図3エステル分解能 (TAMe 活性) とキニン遊 離能の相関性

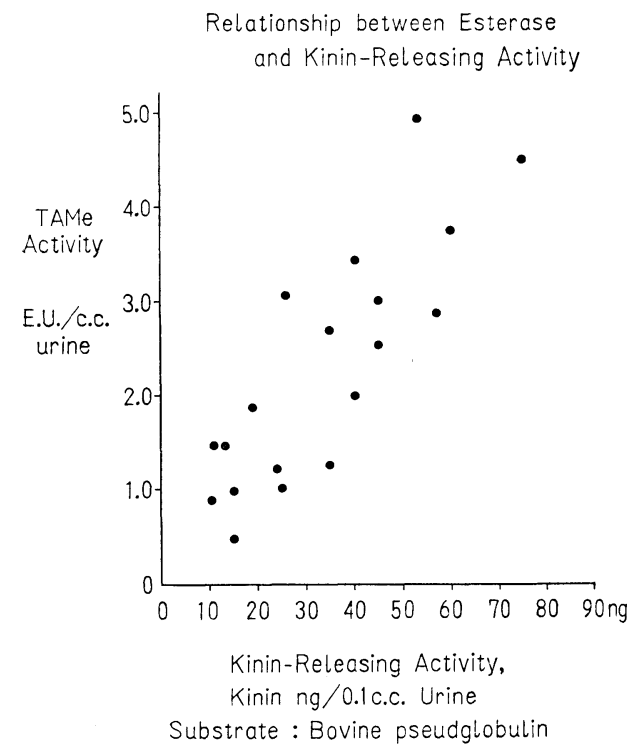

それぞれ，ヒト尿中に溶解せしめ，先に述べた濃縮操 作，TAMe assay を行なつたところ回収率は96\%，102 \%また，水に溶解した場合は，それぞれ86\%，120\%の 回収率であつた（表 1 ）.

4) 再現性
表 1 回収率 ヒト尿, 水に溶解した場合の $\mathrm{TAMe}$ 活性の回収(守屋の方法による)

\begin{tabular}{|c|c|c|c|c|}
\hline & \multicolumn{2}{|c|}{$\begin{array}{l}12.5 \text { E.U. 含有する } \\
\text { ヒト尿 } 300 \mathrm{ml}\end{array}$} & \multicolumn{2}{|c|}{ 水 } \\
\hline $\begin{array}{l}\text { H.U.K. } \\
\text { E.U. }\end{array}$ & $\begin{array}{l}\text { 回 収 } \\
\text { (E.U.) }\end{array}$ & 回収率（\%） & 回収 & \begin{tabular}{|l} 
回収率 \\
$(\%)$
\end{tabular} \\
\hline 25.0 & 36.5 & $\frac{36.5-12.5}{20.0}(96 \%)$ & 21.6 & $86 \%$ \\
\hline 5.0 & 17.6 & $\frac{17.6-12.5}{5.0}\left(\begin{array}{r}102 \\
\%\end{array}\right)$ & 6.0 & $120 \%$ \\
\hline
\end{tabular}

測定標本は, 測定の最終段階で64倍に稀釈されること になり，ある程度までの混浊は測定値に影響しない. 混 浊のある尿およびない尿につきおのおのの測定值間のバ ラツキを調べるために, 各標本を 6 等分し, 括のおのの 標本毎に濃縮, Assay をそれぞれ独立に行ないE.U.を 算出した。混浊尿については，バラッキが大であつた が, 混浊のない尿では, 満足すべき結果を得た（表 2 ）.

表 2 測定のバラッキ（混濁尿）

\begin{tabular}{c|c|c|c|c}
\hline Part & $\begin{array}{c}\text { 吸 光 度 } \\
\text { (O.D. })\end{array}$ & E.U./ml & $\begin{array}{c}\text { 透析尿量 } \\
\mathrm{ml}\end{array}$ & $\begin{array}{c}\text { E.U./ } \\
300 \mathrm{ml} \text { 尿 }\end{array}$ \\
\hline 1 & .550 & 0.7 & 13.5 & 9.5 \\
2 & .475 & 1.6 & 10.0 & 16.0 \\
3 & .500 & 1.3 & 11.5 & 15.0 \\
4 & .460 & 1.8 & 15.0 & 27.0 \\
5 & .490 & 1.4 & 14.0 & 19.6 \\
6 & .535 & 0.9 & 12.0 & 11.8 \\
\hline
\end{tabular}

$(17 \pm 6.2)$

測定のバラッキ（混濁なき尿）

\begin{tabular}{c|c|c|c|c}
\hline Part & $\begin{array}{c}\text { 吸 光 度 } \\
\text { (O.D. })\end{array}$ & E.U./ml & $\begin{array}{c}\text { 㴡析尿量 } \\
\mathrm{ml}\end{array}$ & $\begin{array}{c}\text { E.U./ } \\
300 \mathrm{ml} \text { 尿 }\end{array}$ \\
\hline 1 & .445 & 2.0 & 15.0 & 30.0 \\
2 & .405 & 2.5 & 12.0 & 30.0 \\
3 & .405 & 2.5 & 13.0 & 32.5 \\
4 & .460 & 1.8 & 11.5 & 23.7 \\
5 & .405 & 2.5 & 12.5 & 32.7 \\
6 & .390 & 2.7 & 12.0 & 32.0 \\
\hline
\end{tabular}

$(30 \pm 3.1)$

5）保存による活性の変化

任意にとりだした標本を冷蔵庫内にポリェチレン製容

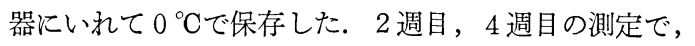
ほとんど活性低下を認めなかつた（図 4). 
図 4

Sampleの保存によるTAME活性推移 $\left(0^{\circ} \mathrm{C}\right)$

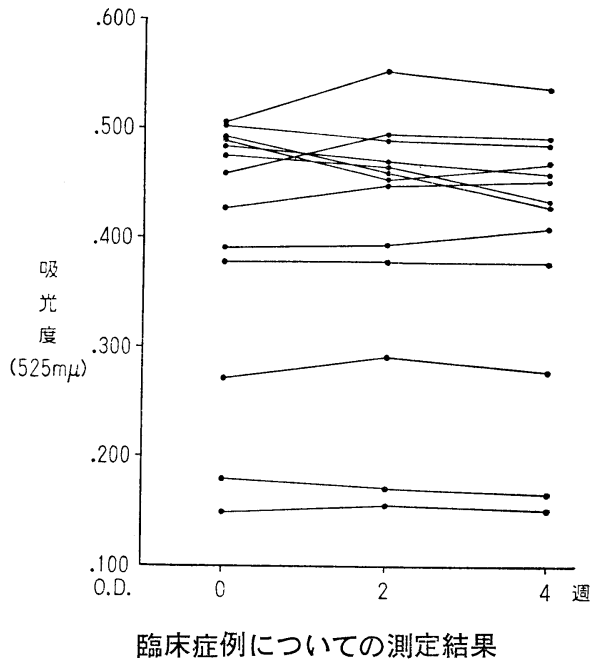

H.U.K. は1 日排泄量 (E.U./day) として算出した. 副腎疾患症例については，手術前後の H.U.K. を測定 した(図 5). 手術対照はホルモンと関係の少ない一般外

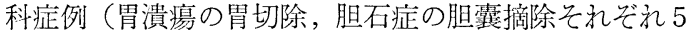

因 5 副㹂手術前後の H.U.K.（原発性アルドステ ロン症は, 腺腫を含む片側副腎摘除, クッシ ング症候群は, 片側腺腫摘除又は両側過形成 副腎全摘除） 1 例は未手術例. 対照として胃 切除及び胆のう摘除.

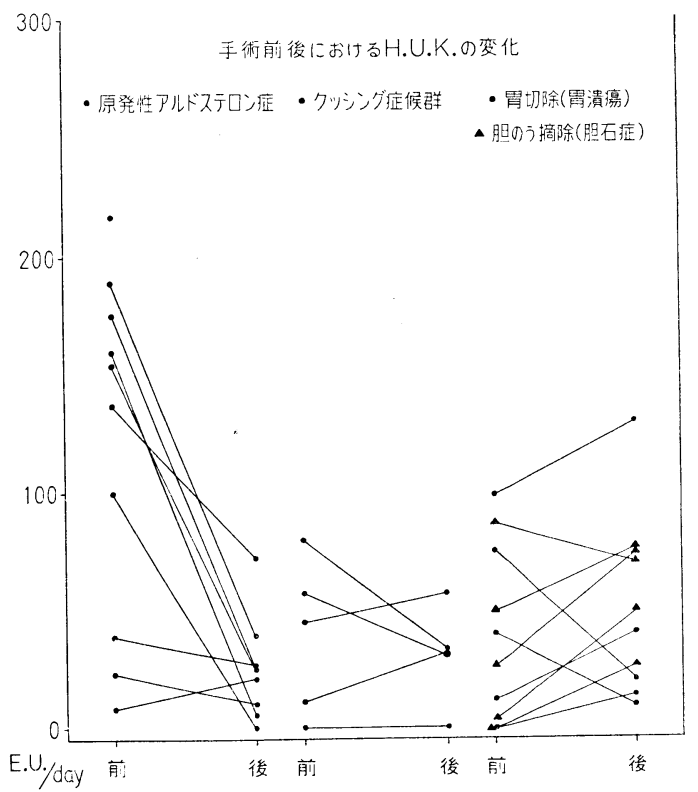

例）について測定した. 腎移植例は, 移植直後（1 週間 以内）より数力月間隔で測定した. 拒絶反応期にお活る 尿は，血尿，混浊等のため測定不能のものが多かつた.

以下, 各疾患群の H.U.K. 值および, 臨床経過につ いて簡単に述べる（図6）。

\section{1）正常例}

生来，腎疾患执よびホルモン異常のない男女 6 例ずつ 測定した。すべて，血中尿素窒素（以下 BUN と略称） $6 \sim 17 \mathrm{mg} / \mathrm{dl}$, クレアチニン $0.8 \sim 1.7 \mathrm{mg} / \mathrm{dl}$ で腎機能は正 常と考光られるもので，年令は男29～32才，(平均31才） 女25３2才，(平均29才)である. H.U.K. 值は男平均63 E.U./day (最高 126, 最低 0 E.U./day), 女平均39 E.U./ day（最高68，最低 0 E.U./day）であつた。

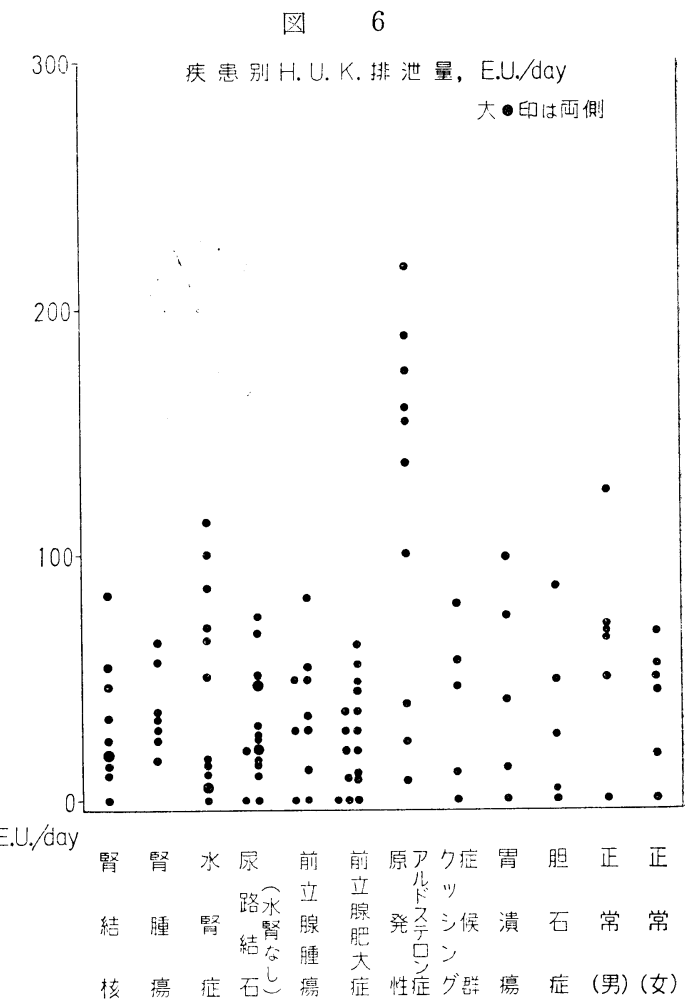

2）腎疾患群

術前 3 回（3日間）の平均值を算出した。腎結核は 9 例であり平均30E.U./day（最高83, 最低 0 E.U./day), 腎 腫瘍 (Grawitz 氏腫瘍) は7 例で平均36E.U./day（最高 64 , 最低 16 E.U./day)，水腎症は11例で平均48E.U./day （最高 113, 最低 0 E.U./day), 尿路結石症（腎および氺 管結石) は15例で平均 30 E.U./day（最高74, 最低 0 E.U./ 
day),この群の腎機能は, PSP 15分值で 0\%のものから 正常のものまで含まれていた.

3）前立腺疾患群

この群では，排尿障害のため腎機能が障害されている 症例が多く, H.U.K. が 0 E.U./day のものが他の群に 比較すると多かつた。

肥大症は16例で平均 27 E.U./day(最高 64 , 最低 0 E.U./ day), 腫瘍は10例で平均36E.U./day（最高82, 最低 0 E.U./day) であつた.

4）副腎疾患群

1. 原発性アルドステロ'ン症症例

症例 1.20 才男

血圧 160 150/110 $100 \mathrm{~mm} H \mathrm{Hg}$ 血清 Na $146 \mathrm{mEq} / \mathrm{l}, \mathrm{K}$ $3.4 \mathrm{mEq} / 1$, H.U.K. は 5 日間（5回）測定し 145，200, 108，400，130E.U./day (平均 137E.U./day) とバラ ツキが大きいがいずれる他の疾患群に比較すると高值 で, 左副腎摘除 (病理診断 Cortical adenoma) の後, 血圧は正常となり，血清 $\mathrm{Na} 139 \mathrm{mEq} / 1, \mathrm{~K} 4.1 \mathrm{mEq} / \mathrm{l}$, 術 後 7 日目の H.U.K. は72E.U./day と術前より著明に低 下した.

症例 2. 51 才女

血圧 175 160/105 95, 血清 Na $146 \mathrm{mEq} / 1, \mathrm{~K} 3.8$ $\mathrm{mEq} / \mathrm{l}$, H.U.K. は 5 日間 ( 5 回) 測定 L， 175，120, 69，238，170E.U./day（平均 154E.U./day）と 4 回ま でが高值を示し, 右副腎摘除（病理診断 Cortical adenoma）の後，1 週間では血圧は変らず，血清 $\mathrm{Na} 133$ $\mathrm{mEq} / \mathrm{l}, \mathrm{K} 4.6 \mathrm{mEq} / \mathrm{l}$ となり, H.U.K. は, 術後 7 日目よ り 5 日間測定 ᄂ $26 ， 10 ， 28 ， 50 ， 10$ E.U./day (平均 25 E.U./day）と，すべて正常人の平均值以下となり，血圧 は1 カ月後に正常となつた.

症例 3.44 才男

血圧 $240 \sim 220 / 140 \sim 120$, 血清 Na $143 \mathrm{mEq} / \mathrm{l}, \mathrm{K} 3.0$ $\mathrm{mEq} / 1$, H.U.K. は， 6 日間（6回）測定し，126，113， $75,62 ， 74 ， 152$ E.U./day (平均 100E.U./day) と正常 人の平均值よりもかなり高く, 左副督摘除 (病理診断 Cortical adenoma) の後, 血清 $\mathrm{Na} 138 \mathrm{mEq} / \mathrm{l}, \mathrm{K} 4.5 \mathrm{mEq} / 1$ となり，血圧は 1 週間後, 術前と変らず，H.U.K.は術 後 $7 ， 8$ 日目にともに0 E.U./day とまつたく活性を示 さなくなつた。

\section{症例 4.30 才女}

血圧 170 150/105 95, 血清 $\mathrm{Na} 144 \mathrm{mEq} / \mathrm{l}, \mathrm{K} 3.9$ $\mathrm{mEq} / \mathrm{l}$, H.U.K. は， 5 日間（5回）測定したが，最高23 E.U./day, 最低 0 E.U./day（平均 8 E.U./day）と浯とん
ぞ活性なく, 左副腎摘除（病理診断 Cortical adenoma） の後, 血圧は 1 週間後に正常化し, 血清 $\mathrm{Na} 140 \mathrm{mEq} / 1$, K 5.0mEq/1 となり, H.U.K.は, 術後 7，8，9 日目 にそれぞれ32，10，21E.U./day（平均21E.U./day）とや や上昇したが，女子正常者の平均までも達しなかつた。

症例 5.39 才女

血圧 180 160/120 100，血清 Na $141 \mathrm{mEq} / 1, \mathrm{~K} 3.0$ $\mathrm{mEq} / 1$, H.U.K. は 5 日間（ 5 回）测定し，240，250, $23 ， 212 ， 220$ E.U./day (平均 189E.U./day) と 1 日だ け低值, 他の 4 日は著しく高值を示したが, 左副腎摘除 (病理診断 Cortical adenoma)の後, 血清 $\mathrm{Na} 137 \mathrm{mEq} / \mathrm{l}$, $\mathrm{K} 4.7 \mathrm{mEq} / 1,7$ 日目，血圧はまだ術前と同じであつたが H.U.K. は術後 7，8，9日目に气れぞれ21，75，21 E.U./day（平均39E.U./day）と平均では, 女子の平均值 まで下降した。

症例 6.32 才男

血圧 180 150/120 105, 血清 Na 149mEy/l, K 3.2 $\mathrm{mEq} / \mathrm{l}$, H.U.K. は， 5 日間（5回）測定し，77，240， 176，188，380E.U./day（平均 160E.U./day）と 1 日 を除いては著しく高値を示し，左副腎摘除（病理診断 Adrenal adenoma) の後, 血清 $\mathrm{Na} 140 \mathrm{mEq} / \mathrm{l}, \mathrm{K} 4.7$ $\mathrm{mEq} / 1$, 血圧も 140/90 と下降し, H.U.K. は $7,8,9$ 日目に17，0，0 E.U./day（平均 6 E.U./day）と低值と なつた。

症例 7 . 39才男

血圧 $230 \sim 190 / 140 \sim 125$, 血清 $\mathrm{Na} 148 \mathrm{mEq} / \mathrm{l}, \mathrm{K} 2.8$ $\mathrm{mEq} / 1$, H.U.K. は，5 日間（5回）測定し， 15，24， 14，31，31E.U./day（平均23E.U./day）と正常男子の 平均よりかなり低值で, 左副腎摘除（病理診断 Adrenal adenoma) の後, 血清: $\mathrm{Na} 140 \mathrm{mEq} / 1, \mathrm{~K} 4.6 \mathrm{mEq} / \mathrm{l}$, 血圧 は1 週間後やや下降をはじめ, H.U.K.は 7，8，9日 目にそれぞれ，16，9，6 E.U./day（平均10E.U./day) と術前後ともに低值で, 著しい变化もなかつた.

症例 8.46 才男

血圧 $190 \sim 175 / 130 \sim 110$, 血清 Na $148 \mathrm{mEq} / 1, \mathrm{~K} 2.6$ $\mathrm{mEq} / 1$, H.U.K. は， 5 日間 ( 5 回) 測定 し， $23 ， 50$, $30,60,30 \mathrm{E} . \mathrm{U} . /$ day (平均 $39 \mathrm{E} . \mathrm{U} . /$ day) と正常男子の平 均より低值であつた。右副腎摘除（病理診断 Adrenal adenoma) の後, 血清 $\mathrm{Na} 144 \mathrm{mEq} / 1, \mathrm{~K} 4.1 \mathrm{mEq} / 1$, 血圧 は1 週間後より 160/110と下降をはじめ, H.U.K.は術 後 $7,8,9$ 日目に，0，28，50E.U./day（平均26E.U.) day）と低值であるが上昇傾向をみせている.

症例 9.39 才男 
血圧 $180 / 100$, 血清 $\mathrm{Na} 144 \mathrm{mEq} / \mathrm{l}, \mathrm{K} \quad 3.0 \mathrm{mEq} / \mathrm{l}, \mathrm{H}$. U.K. は 3 日間（3 回）測定し 190，95，300E.U./day （平均 175E.U./day）と変動が大きいが，いずれも高值 を示し，右副腎摘除（病理診断 Adrenal adenoma)の後, 血清 $\mathrm{Na} 142 \mathrm{mEq} / \mathrm{l}, \mathrm{K} 4.0 \mathrm{mEq} / \mathrm{l}$ ，血圧は 1 週間後 $140 /$ 70 と下降をはじめ, H.U.K.は，術後 8，9，10日目に それぞれ40，15，20E.U./day（平均25E.U./day）と正常 男子の平均値以下となつている。

症例10.40才男

高血圧 180/120のために来院，血清 Na $145 \mathrm{mEq} / \mathrm{l}, \mathrm{K}$ $3.0 \mathrm{mEq} / 1$, 血中レニン $0 \gamma / \mathrm{dl}$ で臨床的に原発性アルド ステロン症と診断され，H.U.K.は 3 日間（3 日）測定 し $350,130,170$ E.U./day (平均 217 E.U./day) と著 しく高值を示しているが手術未施行例である.

以上，本症に打斿術前 H.U.K.は，高值を示すも の 7 例, 正常值以下のもの 3 例で, 平均すると 122 E.U./ day となり， 9 例に副腎腺腫摘除が行なわれ，高值を 示したものは，すべて，術後低下し，1例を除いて正常 值以下となつている. 術前低值を示す群は 3 例あり, 術 後著変を認めなかつた.

ロ，クッシング症候群

症例 1.37 才女

術前 H.U.K. は 3 日間( 3 回) 測定し 7，0，26E.U./ day (平均11E.U./day), 左副腎摘除（病理診断 Adrenal adenoma) の後 7 11日目の H.U.K. は，28，38，11， 0,72 E.U./day（平均32E.U./day） と, 術前後共, 女子 の平均値以下で著変なく, 術後の経過は良好である.

症例 2.2 才男

術前 H.U.K. は 3 日間（3 回）測定し $0 ， 1.2 ， 0$ E.U./day（平均 0.4E.U./day）とほとんど活性を示さ ず，右副腎摘除（病理診断 Adrenal adenoma）の後, H.U.K.は術前と変らず，7 日目から12日目までいずれ も0 E.U./day であつた.

症例 3.38 才女

術前 H.U.K. は，4 日間（4回）測定し，36，24， 40，80E.U./day（平均45E.U./day）で女子の平均値より やや高く, 左副腎摘除 (病理診断 Adrenal adenoma) の後，H.U.K. は，7日目〜10日目にそれぞれ 0，20， 114，94E.U./day（平均57E.U./day）とやや上昇してい る.

症例 4.42 才女

術前 H.U.K.は，3 日間（3 回）の測定で83，40， 47E.U./day（平均57E.U./day） と女子の正常值よりやや
高く, 両側副腎摘除（病理診断 Adrenal hyperplasia）の 後, H.U.K. は7 日目〜9日目にそれぞれ 33，45，12 E.U./day（平均30E.U./day）と女子の平均值よりもやや 低值となつた。

症例 5 . 28才女

術前 H.U.K. は 3 日間 ( 3 回) 測定 L65，95，80E.U./ day (平均 80 E.U./day) と，3 回ともに女子の平均值より 高値を示し, 両側副腎摘除 (病理診断 Adrenal hyperplasia）の後， 7 日目〜 9 日目の H.U.K. は28，40，20 E.U./day（平均33E.U./day） と女子の平均値よりやや低 なつた。

以上，本症の術後は，症例 1 から 3 までは，腺腫のた め他側の副腎は萎縮して扮り，ハイドロコーチゾンによ る補充を, 症例 4,5 は, 過形成のため両側副腎全摘除 を行ない，同じく， ハイドロコーチゾンによる置換療法 が行なわれている。

手術前後の H.U.K. の変動は症例 1 から 3 までの腺 腫例では， 3 例中 2 例（1 例は不变）はやや上昇傾向 を, 症例 4，5 ではともに下降する傾向をみせている. 全体の平均値は術前39E.U./day, 術後31E.U./day であつ た.

5）一般外科症例

副腎疾患患者の手術前後の H.U.K. 測定を行なつた ので, その対照群として, 胃および副腎と関係が少いと 考兄られる胃潰瘍患者の胃切除, 胆石症患者の胆囊摘除 をそれぞれ 5 例ずつ計10例について, 術前 3 日間, 術後 $7 \sim 9$ 日目に 3 日間 H.U.K. を測定し平均值を算出 乙 た。

胃切除例では，術後上昇を示したものは，3 例（99 130 E.U./day, $12 \rightarrow 40$ E.U./day, $0 \rightarrow 13$ E.U./day), 低下 を示したものは 2 例 $(75 \rightarrow 20$ E.U./day, $40 \rightarrow 10$ E.U./day) あり, 術前平均 45 E.U./day, 術後平均 43 E.U./day とな り，一定傾向は認められなかつた。

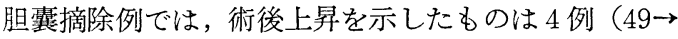
76 E.U./day, $26 \rightarrow 74$ E.U./day, $4 \rightarrow 50$ E.U./day, $0 \rightarrow 26$ E.U./day), 低下を示したものは 1 例（87 $\rightarrow 70$ E.U./day） で平均すると術前33E.U./day, 術後59E.U./day となりい ずれも男女の正常例の平均值近い值であるが，胆囊摘除 例では, H.U.K. は上昇するといえる.

6）腎移植症例（図 7)

症例 1.23才男，原疾患：腎結核

腎出血患者（無血縁者）の腎を移植された。拒絶反応 期は, 第 1 回が術後 $1 \sim 2$ 週目，第 2 回が， $3 \sim 4$ 週目 
図 7 腎移植後の H.U.K. 7 例（死亡 6 例, 生存 1 例)

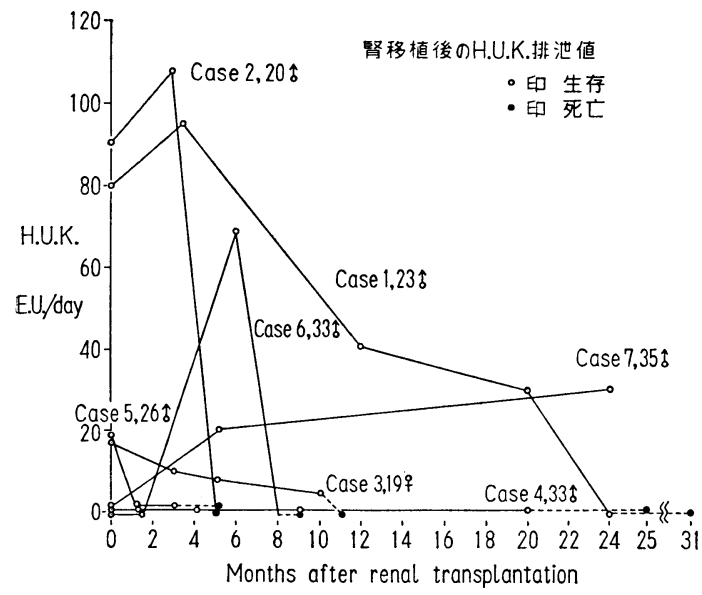

である.

H.U.K. は, 移植直後 ( 3 日目) そ80E.U./day この時 の血中尿素窒素 (以下 BUN と略称) は $30 \mathrm{mg} / \mathrm{dl}, 3$ カ月 半後の H.U.K. は90E.U./day (BUN $25 \mathrm{mg} / \mathrm{dl}$ ), 12 カ月後 は40E.U./day (BUN 40mg/dl),20カ月後30E.U./day (BUN $74 \mathrm{mg} / \mathrm{dl}$ ),24カ月後 0 E.U./day (BUN $154 \mathrm{mg} / \mathrm{dl}$ ) と次第に 下降し,さらに, 数カ月後腎不全のため死亡した.

症例 2. 20才男, 原疾患: 慢性腎炎

父より健腎を移植された. 拒絶反応期は, 第 1 回が 1 $\sim 2$ 週目, 第 5 週より慢性の拒絶反応期に入つている. H.U.K. は，移植直後より 4 日間は， $120 ， 85 ， 106$, 50 E.U./day (平均90E.U./day, BUN $32 \mathrm{mg} / \mathrm{dl}$ ), 3 カ月後, 108E.U./day (BUN 35mg/dl), 4 カ月半になると0 E.U./ day (BUN 90mg/dl) となり, この測定の 2 週後, 腎不全 で死亡した。

症例 3.19才女, 原疾患: 慢性腎炎

腎出血患者の腎（無血縁者）を移植された。拒絶反応 期は， $1 \sim 2$ 週目に 1 回あつた. H.U.K. は 2 日目 4 日目に $25 ， 14 ， 10$ E.U./day (平均17E.U./day, BUN 34 $\mathrm{mg} / \mathrm{dl}$ ), 3 カ月後は, 10E.U./day (BUN $25 \mathrm{mg} / \mathrm{dl}$ ), 5 カ月 後 8 E.U./day(BUN 20mg/dl), 10カ月後 5 E.U./day(BUN $105 \mathrm{mg} / \mathrm{dl}$ ) と BUN の上昇とともに H.U.K. は逆に低 値となり11カ月目に腎不全のため死亡した。

症例 4 . 33才男, 原疾患: 慢性腎炎

腎出血患者の䁂（無血縁者）を移植された，拒絶反応 は第 1 回 $1 \sim 2$ 週目, 第 2 回は $5 \sim 6$ 週目にみられた.

H.U.K. は術直後から 5 日間まつたく活性を示さず， 1 カ月後, 4 力月後, 9 カ月後, 20 カ月後も同様注とんど
0 E.U./day で BUN はその間 $40 〜 50 \mathrm{mg} / \mathrm{dl}$ で腎機能とし ては比較的よく保たれた例である。 2 年 1 カ月後になり 合併症のため死亡したが, H.U.K.は 1 度も上昇傾向を みなかつた。

症例 5.26 才男, 原疾患: 慢性腎炎

冉から健腎を移植された. 第 1 回拒絶反応は $2 \sim 5$ 週 目にかけて長期にわたり，6週目の終り頃から慢性の拒 絶反応期に入り，それ以後，腎機能は，回復することな く，5 カ月目に腎不全のため死亡した. H.U.K. は, 移 植直後より，6 日間測定し，26，0，23，6，39，12 E.U./day (平均18E.U./day, BUN $17 \mathrm{mg} / \mathrm{dl}$ ), と低值であ り，1 カ月後, 3 日間（3 回）の測定值はすべて0 E.U./ day (BUN $120 \mathrm{mg} / \mathrm{dl}$ ) で, 3 カ月後, 0 E.U./day (BUN $111 \mathrm{mg} / \mathrm{dl})$ と下降してしまつている.

症例 6.34 才男, 原疾患：慢性腎炎

腎出血患者の腎（無血縁者）を移植された。早期拒絶 反応はなかつた. H.U.K.は直後より 7 日間（7回）測 定し，0E.U./day（7 日間）で，BUN は27〜30mg/dlで あつた。

1 カ月半後は, 2 日間 (2 回) 測定しともに, 0 E.U./ day (BUN 30mg/dl)，6 カ月半後は，3 日間（3 回）の 測定で25，75，104E.U./day（平均68E.U./day, BUN 40 $\mathrm{mg} / \mathrm{dl})$ とやや回復しているが，8カ月後，3 日間測定し すべて 0 E.U./day (BUN 55mg/dl) と下降し， 9 カ月目 に腎機能不全のため死亡した。

症例 7. 35才男, 原疾患: 慢性腎炎

同胞より健腎を移植された. 拒絶反応は現在 2 年 1 力 月までない. H.U.K.は, 直後より 5 日間（5回）測定 し, いずれも 0 E.U./day (BUN 27〜 43mg/dl), 5 カ月後 は3 日間（3 回）の測定で， 9，30，21E.U./day（平均 20 E.U./day, BUN $15 \mathrm{mg} / \mathrm{dl})$ とやや回復し! 2 年後は, 30 E.U./day (BUN 25.5mg/dl) と低值ながら上昇傾向がみ られる. 現在，腎機能はよく保たれ，社会復帰をしてい る症例である。

以上の腎移植患者は, 免疫抑制剂として, プレドニン 拈よびイムラン (Azathiopurine) を拒絶反応の程度に応 じて連続投与されている.

腎移植後の H.U.K. の推移をまとめると, 直後 (1 週間以内）は此較的高値を示す群（2 例）と, 著しく低 值の群（5例）がまずみられる. その後, 高值群では, $3 \sim 4$ カ月後に, 一時やや上昇を示すが, 漸次低下する ものと急激泜下寸るものが 1 例づつあつた. 低值群 5 例の中 3 例は, 以後, 漸次低下し, E.U./day またはそ 
図 8 PSP $を$ H.U.K. の相関

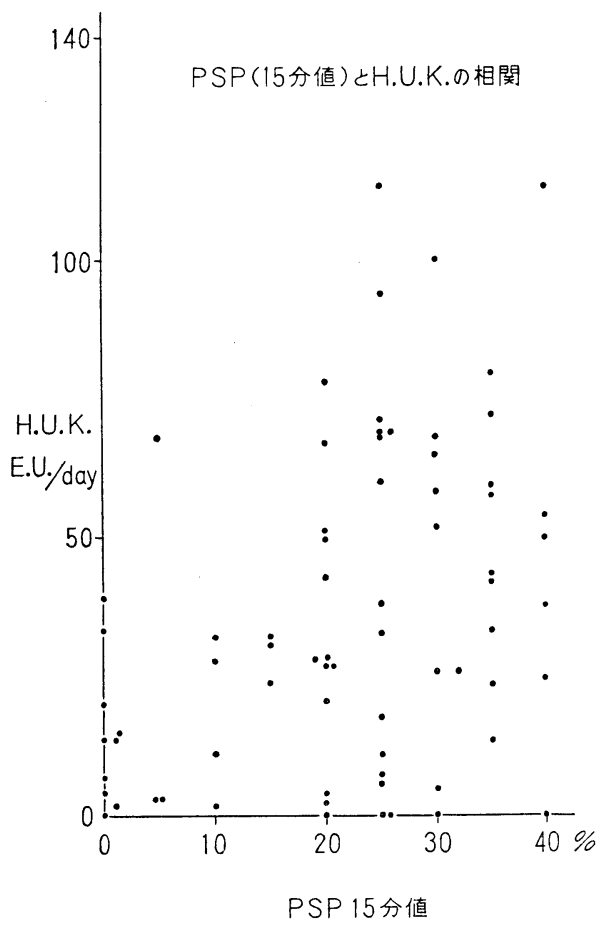

れに近くなり死期を迎えている．5 例中の他の 2 例は， それぞれ 5 力月, 6 力月半以後, 上昇傾向をみせたが 1 例は， 2 年後さらに上昇傾向をみせ，腎機能も上く保た れて拈り，他の 1 例は，その後急激に下降し，死亡して いる.

7） PSP 15分値と H.U.K.

腎疾患群，前立腺疾患群，一般外科症例群に扮いて行 なつた PSP 検査成績と H.U.K. の関係を検討した（図 $8)$.両測定值間には，はつきりした相関関係は見出せな かつたが PSP 低值群では，H.U.K. も著しく低から た。

\section{考按}

歴史的考察

Frey, $\mathrm{Kraut}^{2}{ }^{2}$ らは，1926年，ヒト，イヌの透析尿を麻 酔犬に注射し，血压降下を観察し，「腎から排泄され 心機能を刺激する物質」として, ある物質を報告した。 その後, このような物質は，膵，血浆にも含まれ，とく に膵には多量に存在することがわかり，カリクレインと 命名された。ささらに，カリクレインは，十二指腸液， 冀，唾液からも発見されている。

$\mathrm{Werle}^{3)}$ は，1937年，この尿と血浆をインキユベイト
し，この時遊離した物質は，血圧降下作用の外にモルモ ット腸管收縮作用のあることを発見した。これは，尿中 カリクレインが血浆に作用して遊離されたものと考えら れ，今日では，この物質はカリジンであるといわれてい る.

一方, Rocha e Silva ${ }^{4)}$ は，蛇毒の少量をイヌに注射 したところ，ショック性の血圧降下を示し，この時血中 に，モルモットの腸管収縮物質が生成されていることを 発見した。この物質は，血中から速やかに消失し，数分 後に採血した血浆にはすでにこのような作用は認めら れなかつた。彼は, この物質について, ヒスタミン, ト ロンボサイチン，カリクレイン，アセチルコリン等とは 薬理学的にまつたく違つた新しい物質であるとして，ブ ラジキニン (Bradykinin) の名を与えた。 これは，血浆 グロブリン分画から蛇毒中の酵素により遊離されたるの と考光られ，Werle のカリジンが尿カリクレインによ り遊離されることと相通ずるものである. Rocha e Silva はブラジキニンの前駆体にブラジキニノーゲン (Bradykininogen), Werle は後に, カリジンの前駆体にカリジ ノーゲン(Kallidinogen) と命名した. ブラジキニン，カ リジンは生体中にあるキニンの代表的なもので，血浆の $\alpha_{2}$-グロブリン分画中の前駆体にトリプシンおよびカリ クレインが作用し遊離される。 その後，これらキニンの

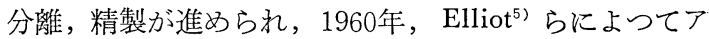

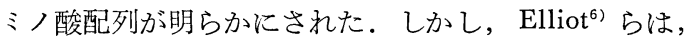
最初,ブラジキニンの構造を H-Arg-Pro-Gly-phe-Ser-pheArg-OH と推定 したが，これは活性を示さず，結局， Guttman，Boissonas らによつて訂正されて H-Arg-ProPro-Gly-phe-Ser-Pro-Phe-Arg-OH が天然品と生理活性が 一致することがわかつた。 また，カリジンは，アミノ酸 10コからなるぺプチドでブラジキニンのN末に lysine のついたもので, lysyl-Bradykinin とも呼ばれる.この 2つのペプチドは定性的にはまつたく同じ生理作用をも ち，定量的には，それぞれ測定される生理作用により差 があるが，ともに血圧降下，腸管収縮作用のほかに血管 抎張，毛細血管透過性六進，白血球遊走，疼痛発生等の 作用を有する。

キニノーゲンにカリクレインが作用し，キニンを遊離 する酵素系をカリクレインーキニン系と称し，その生理

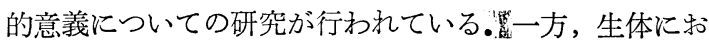
いては, 血液凝固系, プラスミン系との関係も複雑で, こ れらの酵素を無視して，キニン系のみを明らかにするこ とは不可能であるが，本酵素系を構成する各因子の測定 
法が開発されるようになり，いくつかの疾患において， その病態生理にキニン代謝が関与していることがわから て来た.

カルチノイド症候群は，1950年代に批いて，七ロトニ ン代謝との関係が明らかにされた。

しかし，1962年，Peart ${ }^{7)}$ らは，カルチノイド患者にセ ロトニンを注射しても本症に特有な flushing 現象は招 こらず，また flushing 発作中でも，血中セロトニン值は 必ずしも上昇していないことを報告し，七ロトニン以外 の物質が本発作の誘起物質であることを示唆した。 Oat$\mathrm{es}^{8}$ は，1964年，ブラジキニンを本症患者に注射し，flushing, 頻脈，血圧降下，呼吸促進等を観察し，またェピ ネフリンの静注により内因性のブラジキニンを誘発し ても同じ結果を得た．さらに，カルチノイド腫湯より抽 出したキニンを合成ブラジキニンと比較検討し，両者は まつたく同じものであることを示した. Dean"9 は Spontaneous flushing とブラジキニン注射による flushing の 血行動態を血圧, 血管抵抗, 心搏出量等により比較し, この両者はほとんど同じ時間的推移を示したと報告し た.かくして,カルチノイド症候群に打ける病態生理に ブラジキニンが重要な役割をはたしていることがわかつ てきた.

遺伝性血管運動神経性浮嗹 ${ }^{10) 11}$ に扔いては，先天的に カリクレインインヒビターの欠乏があるといわれて拉 り，カリクレインが血中に増えるためにキニンが遊離さ れやすくなり，血管の透過性九進が局所的におこり，浮 腫を生ずると説明されている。

Melmon ${ }^{12)}$ は，ブラジキニンが羊の動脈管ととトの䏴 動静脈を収縮させることに注目し，ヒト新生児の䏴帯 血中のブラジキニン和よびブラジキニノーゲンの測定 を行ない，ブラジキニンは成人に比較して新生児に高 く, キニノーゲンは低いとしている. 新生児顆粒白血球 にはキニナーゼが低く, カリクレインは㑪血管を通る際 の温度低下により活性化されることを示し，胎児から新 生児への新しい循環, すなわち, 動脈管, 䏴動静脈の収 縮および肺循環が開始されるための血管㧪張にカリクレ インーキニン系が関与していることを示した。

Hilton, Lewis らは，カリクレインは生体のあらゆる 組織に証明されることから，特に腺性カリクレインに注 目し, キニン遊離により腺活動への関与を主張してい る.

急性膵炎は胆管からトリプシンのごとき蛋白分解酵素 が脺組織内に逆流するために扤こるといわれ，実験的に
も動物に逆流をつくることにより怙こすことができる. この際トリプシンは, 脺内のカリクレイノーゲンに作用 し活性カリクレインとする一方，キニノーゲンに作用 し，キニンを遊離し，これが急性膵炎の誘起物質とな り，血管透過性亢進，ショック性の血圧降下を括こすと 考光られている，七トの急性膵炎は，カリクレインのイ ンヒビターとして知られるトラジロール (Trasylol) が 治療上有効なことが知られている。キニンは，また，生 体の局所に，急性炎症像をつくることができ，セロトニ ン，ヒスタミンと同様に炎症誘起物質としても注目され ている。

腎に拈けるカリクレインーキニン系の研究は, H.U.K. の測定から始められた，H.U.K.はいまだその最終産物 までは精製されておらず，生化学的な性質等については 明らかでないが各種阻止物質に対する反応，実験的腎障 害と尿性カリクレインの消長等から腎より排泄されてい ると考兄られている。

$\mathrm{Miwa}^{13)}$ は，ヒト血清を基質としたキニン遊離能によ り H.U.K. の測定を行なつたが，高血圧症，腎疾患患 者, 拈よび正常人の間に有意差を見い出していない.

Horton $^{14)}$ らも同じ方法でH.U.K. を測定し，正常人で 1 日 292〜 440単位 (Frey Unit) であると報告した。

Moriya は，TAMe を基質とした化学的定量法1をを用 い, 正常人で安静時の 24 時間値 は20〜63単位（Esterase Unit）で, 停止性担癌患者よりも進行性の例にH.U.K. の增量がみられたと報告している。この他, Frey, Kraut らのイヌの血圧降下作用を利用したものがあるが, H.U. K. の特別高いものや低い疾患は見い出されてはいない。 また，草食よりも肉食のヒトに H.U.K. が高いことも 報告されている.

以上のごとく，H.U.K. 測定の報告は散発的に見られ るが，腎生理との関係を明らかにするまでには至つてい ない。

\section{測定法 ${ }^{15)}$}

カリクレインは，一般には，キニノーゲンからキニン を特異的に遊離する酵素々定義されて㧤り，その測定 法 ${ }^{15}$ は，実験動物を用いる方法と，合成基質を使う方法 がある．前者は動物の血圧降下，血流増大作用を利用す る方法と，粗製キニノーゲンを基質として，生成したキ ニンをモルモット回腸，ラット子宮の収縮作用を利用す る方法があり，これは，特異性にすぐれている，血圧降 下による方法は，十分深い麻酔をかけないと安定した血 圧変化が得られないこと, 特異性の低いこと, 感度の低 
いことなどの欠点がある。事実，イヌの血圧降下物質は カリクレインだけではないので, ある程度以上の精製が ないと満足な結果は得られない。 また方法も煩雑であ る. 合成基質を用いる方法は, 簡単に行なえて, 再現性 もよいが，唯一の欠点は特異性が低いことである.

カリクレインにより分解される合成基質は, TAMe (tosyl-1-Arginine methyl ester) BAMe (benzoyl-l-Arginine methyl ester) BAEe (benzoyl-1- Arginine ethyl ester) 等があり, これらのものと検体の反応後, 分解さ れずに残つた基質，または，分解産物を測定することに より酵素活性を知ることができる。

Webster ${ }^{16)}$ はインヒビターによる実験から TAMe はカ リクレイン測定の基質として適していることを報告し， 1964年，守屋は, H.U.K. 測定の場合は, 尿中に TAMe 分解酵素の混有はなく, したがつて TAMe を基質とし て用いられることを示し, Hestrin 法の原理を使つた TAMe Assay を発表した. すなわち, H.U.K. のいくつ かの精製段階に沶いて，TAMe 活性とイヌの血圧降下 作用による測定值はよく一致し，人尿標本に拈いても 両活性はよく一致した。本研究では, さらに, 守屋の TAMe Assay とキニン遊離能の間に満足すべき相関関係 を認めた。 しかし, キニン遊離能と TAMe 活性が一致 しない人尿標本もあつた. 回収率, 再現性, 保存等につ いても，満足すべき結果を得たが，混浊尿については， 再現性がないので, 最終段階で吸光度に影響する標本は 測定対象から除外した。 また，着色の影響を消去するた めに, 予め T.C.A. を加えヒドロキサミック酸生成のな きものを対照として補正を行なつた。

腎とカリクレインーキニン系

イヌの腎動脈へキニンを注入すると， RBF の上昇， 水, 電解質の排泄増大がみられるが, GFR は必ずしも 上昇しない(17)18199). ヒトにキニンを静脈注射しても， GFR の上昇はなく, RBF の上昇掞よび, 水, 電解質の 排泄増大がみられる ${ }^{20)}$. RBF の上昇は, キニンの血管 拡張作用によるものと考光られるが, 水, 電解質排泄増 加は, 系球体毛細管の拡張のみでは説明できない。

守屋 ${ }^{21}$ らによると, H.U.K. の分子量は, 40,500 ヒ

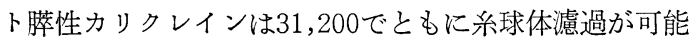
な大きさであるが，各種インヒビターに対する反応，次 に述べる Werle らの実験等より, 腎尿細胞から排泄さ れると考兄られている. Werle ${ }^{221}$ は, ラットの腎尿細管 を選択的に障害させたところ，尿中カリクレイン排泄低 下を認め，尿カリクレインは尿細管で合成，排泄される
とした. Zickgraf ${ }^{23)}$ の考兄も，H.U.K.は，尿細管で合 成，排泄されるとし，尿細管細胞の膜透過性に影響を 与光, 尿細管の再吸収, 排泄作用に対してある役割を演 じていると考えている. 著者の PSP と H.U.K. の関係 で, PSP 值の著しく低値のものは, 尿細管の萎縮, 変 性が高度で細胞自体の機能も障害され, 酵素合成能もと もに低下していると考学られ，したがつて，このような 例では, H.U.K. 值も低かつた。 また, PSP が正常值を 示す例は, 細胞自体の機能もよく, H.U.K. も正常拉よ び正常值以上の值を示するのが多くなるが，PSP は生体 にとつては，単なる異物で偶然尿細管から排泄されるに すぎず，一方，H.U.K.は，生体の一つの酵素系を形成 する酵素で尿細管細胞内で合成，排泄されるもので，排 泄のメカニズムはまつたく異なると考兄られるので, PSP と H.U.K. 值は，必ずしも相関がないものと考兄 られる.

臨床例に括ける H.U.K. 測定結果

正常例の平均值（男63E.U./day，女39E.U./day） と他 の疾患群の平均值を比較すると, 多少の差は認められる が，各疾患別に 1 例づつ, H.U.K. 值をグラフ上にプ ロットしてみると, 原発性アルドステロン症を除いて, 正常例と各疾患群との間には有意差は認められなかつ た。そこで，有意差をもつて高值を示す例の多かつた原 発性アルドステロン症を中心に考察を行ない，腎移植 症例については，腎機能との関係をみながら，術後の H.U.K.の推移を検討した.

アルドステロゾは，遠位尿細管に働き， $\mathrm{Na}$ ，水の貯 留, Kの排泄増大作用をもつ. カリクレインーキニン系 は, $\mathrm{Na}$, 水に関しては, アルドステロンと逆の作用, す なわち，排泄増大，Kに関しては，ともに排泄増大作用 を有する. しかし, この系のみで, 水, 電解質の代謝を 説明することはできないが， $\mathrm{Na}$, 水のバランスといら立 場からすると, カリクレイン一キニン系は, 本症の場 合，生体にとつて都合のよい一つの系であるとい方よ う.しかし，H.U.K. 高値がそのまま腎に拈けるキニン 作用の増大とするには問題があるが, 本症においては, H.U.K. 高值のものが多く, しかも, 副腎腺腫摘除後 は, H.U.K. 高值のものは, すべて, 低下傾向を示した ことは, Na, 水の代謝に関して, H.U.K. が何らかの役 割をしていることを示唆していると思われる. しかし， 少数例ながら, 本症に扔いても H.U.K. の高くない例 もあり, 生体の恒常性維持の面から他の系の関与も考兄 られ今後の検討を要する。 
同じく副腎疾患であるクッシング症候群では, 少数例 でありなお検討を要するが，術前著しく高值を示す例は なく,術後も大きな变動はなかつた。一般外科症例にお いては, 術後上昇するものが 7 例, 低下するものが 3 例 あつたが，ともに，正常者の平均值近くの変化であつた.

副腎疾患患者の H.U.K. 測定のまとまつた報告はみ られないが，動物において，尿カリクレインが，副腎 により支配されるとする報告がある。すなわち，Werle ${ }^{24)}$ は，ラットの両側副䉰全摘除により血中キニノーゲン が 2.5 倍, 両側腎全摘除により 3.5 倍にそれぞれ増加し たことを観察し，腎に拈けるカリクレイン合成が，低下 または皆無となつたため，血中キニノーゲン消費が減つ たものと考光た：さらに，両副腎を摘除した例について， コーチゾンを投与したところ，尿性カリクレイン排泄は 正常化したと報告している.

著者の副腎疾患に抢ける H.U.K. 測定結果より, H. U.K. 高值の原発性アルドステロン症に执いては，アル ドステロンによる H.U.K. への影響を示唆していると 思われる。

クッシング症候群では, 術後, 十分量のハイドロコー チゾンの補充が行なわれているので術前後の H.U.K. の比較はむずかしい，以上，著者の副腎疾患症例に抢け る副腎皮質ホルモンと H.U.K. の関係については，コ ーチゾールよりもアルドステロンによる，H.U.K.のコ ントロールが考えられる.

腎移植後の H.U.K. の推移については, まず直後で は， 7 例中 5 例が著しく低值を示し, Werle ${ }^{25)} ら の$ 述べ ているごとく一時回復をみたものはその中 2 例, 他の 3 例は，上昇傾向をみることなく，漸次低下し死期にはま つたく活性を示さなくなつた，7例中 2 例は，直後より， 比較的高値を示したが，その後やや上昇傾向をみせた のみで, 次第に低下し前述の群と同じょうに死期近くに はまつたく活性がなかつた。拒絶反応期には，BUN の 上昇に先行してH.U.K. の低下がみられることは, We$\mathrm{rle}^{25)}$ らが指摘しているが，著者の例では，BUN の上昇 するものは必ず H.U.K. の低下を伴い，拒絶反応に関 倸なく，BUN の上昇拉よび腎不全の徵候が現われない 時期にすでに H.U.K. が 0 または著しく低值を示す例 が 3 例（症例 $3 ， 4 ， 6$ ） あつた。

移植腎では, 拒絶反応により, 小血管, 系球体が障害 をらけ，ひきつついて尿細管が障害されているといわれ ているが，BUN と H.U.K. 值からみるとむしろ逆に 尿細管に関係の深いH.U.K. の低下が先行している.
これは，尿細管における H.U.K. 合成能は，非常に軽 度な循環障害によつても影響を受けるためと考兄られ る. また，これら少数例から H.U.K. 值と予後の関係 について結論は出せなかつたが，H.U.K. の低下は， BUN 上昇の前ぶれとして，または，尿細管にお汁るH. U.K. 合成能という特殊な機能を反映するものとして注 意すべきであろう。

キニンは，生体中でカテコールアミンによつて誘発さ れ，逆に，キニンにより副腎髄質が刺激されることも知 られている.最近は，さらに，レニンーアンギオテンシ ン系との関連に招いて，本酵素系を考える者もあり， Ueki ${ }^{26)}$ は，イヌの腎皮質飞扝将るレニンおよびカリク レイン両酵素の高活性を見出している.

生体の内部環境を維持するためのいくつかの酵素系が 現在知られているが，原発性アルドステロン症におい て, H.U.K. 高值の例が多かつたことは, カリクレイン 一キニン系もまたこうした恒常性維持のための一つの系 として働いている可能性が強い.

\section{結 語}

1. ヒト尿性カリクレイン (H.U.K. ) 排泄值を測定 するために, 守屋の化学的定量法 (TAMe Assay) を生 物学的方法と比較検討し, 満足すべき結果を得たので, 本法を用いて，H.U.K. を測定した。

2. 腎疾患群，前立腺疾患群と正常群の間には, H.U. K.について有意差はなかつたが，原発性アルドステロ ン症においては，高值を示す例が多く，高値例では，腺 腫を含めた片側副腎摘除により低下する傾向を見た，尿 細管に持けるアルドステロン拈よびキニンの水, $\mathrm{Na}$ 代 謝に対する作用を考えると，H.U.K. 高値のアルドステ ロン症の場合は, 生体の内部環境維持のために, カリク レインーキニン系が活性化されている可能性を示唆して いると考えた。

3. 腎移植後の H.U.K. は 7 例中 5 例は，移植直後 に打いて著しく低值で，その後，一時回復する例もあつ たが，死亡例については，死期に至るまで漸次低下し， まつたく活性がみられなくなつた。

比較的高值を示した 2 例は，さらに上昇傾向をみた が，ともに死期には 0 E.U./day まで下降した。 これら のH.U.K. 低下は，Werle らが指摘したように，BUN の上昇に先行して低下する例が多かつた.

稿を終るに当り, 終始御指導, 御校閲をいただきまし た恩師高安久雄教授支に心上り感謝致しますと共に, 研 究遂行のために御援助下さつた米瀬恶行講師, 藤田公生 
博士はじめ医局員諸兄に感謝致します。

また, 本研究のカリクレイン測定について御指導いた だいた東京理科大学薬学部生理化学教室守屋筧教授, 森 眑千秋助教授はじめ教室員諸见に愿く御礼申し上げま $-\frac{1}{9}$.

なお，本研究の一部は文部省武験矿究費によつた。 本論文は東京大学審查学位論文であとことを附記す z.

\section{文献}

1) 守屋 寛 : 日本臨斨，22，2659，1964。

2) Frey, E.K. und Kraut, H.: Z. physiol. Chem., 157, 32, 1926.

3) Werle, E. und Grunz, M.: Biochem. Z., 301 : 429, 1939.

4) Rocha e Silva, M., Beraldo, W.T. and Rosenfeld, G.: Am. J. physiol., 156, 261, 1949.

5) Elliot, D.F., Lewis, G.P. and Horton, E.W.: Biochem. Biophys. Res. Commun., 3, 87, 1960.

6）鈴木友二, 林恭二：蛋白質核酸酵素, 12, 211, 1967.

7) Robertson, J.I.S., Peart, W.S. and Andrews, T.M.: Quart. J. Med., 31, 103, 1962.

8) Oates, J.A., Pettinger, W.A. and Doctor, R.B.: J. Clin. Invest., 43, 173, 1964.

9) Dean, T.M. and Melmon, K.L.: J. Clin. Invest., 45, 1685, 1966.

10) Landerman, N.S., Webster, M.E., Becker, E.L. and Ratcliff, E.E.: J. Allergy, 33, 330, 1962.

11) Burdon, K.L., Quency, J.T., Thomas, O.C. and McGovern, J.P.: J. Allergy, 36, 546,
1965.

12) Melmon, K.L., Cline M.J., Hughes, T. and Nies, A.S.: J. clin. Invest., 47, 1295, 1968.

13) Miwa, I.: Tohoku J. exp. Med., 86, 334,

14) Horton, E.W.: J. Physiol., 148, 267, 1959.

15) Trautschold, I.: Assay method in the Kinin System Handbook of experimental pharmacology XXV, p 69-75, Springer-Verlag, BerlinHeidelberg-New York, 1970.

16) Webster, M.E. and Pierce, J.V.: Proc. Soc. expl. Med., 107, 186, 1961.

17) Furuyama, T., Suzuki, C., Saito, H., Onozawa, Y., Shioji, R., Rikimaru, S., Abe, K. and Yoshinaga, K.: Tohoku J. exp. Med., 89, 69, 1966.

18) Webster, M.E. and Gilmore, J.P.: Am. J. physiol., 206, 714, 1964.

19) Gill, J.R., Melmon, K.L., Gillepsie Jr., L. and Burtter, F.C.: Amer. J. Physiol., 209, 844, 1965.

20) Barraclough, M.A. and Mills, I.H.: Clin. Sci., 28, 69, 1965.

21) Moriya, H., Pierce, J.V. and Webster, M.E.: Ann. N.Y. Acad. Sci., 104, 172, 1963.

22) Werle, E. und Vogel, R.: Arch. int. Pharmacodyn., 126, 171, 1960.

23) Zickgraf, R.G.: Z. physiol. Chem., 349, 930, 1968.

24) Werle, E., Leysath, G. und Schmal, A.: Z. physiol. Chem., 349, 107, 1968.

25) Werle, E., Busse, R. und Schmal, A.: Klin. Wschr., 24, 1315, 1968.

26) Ueki, H.: Personal Communication.

(1971年 2 月 3 日受付) 